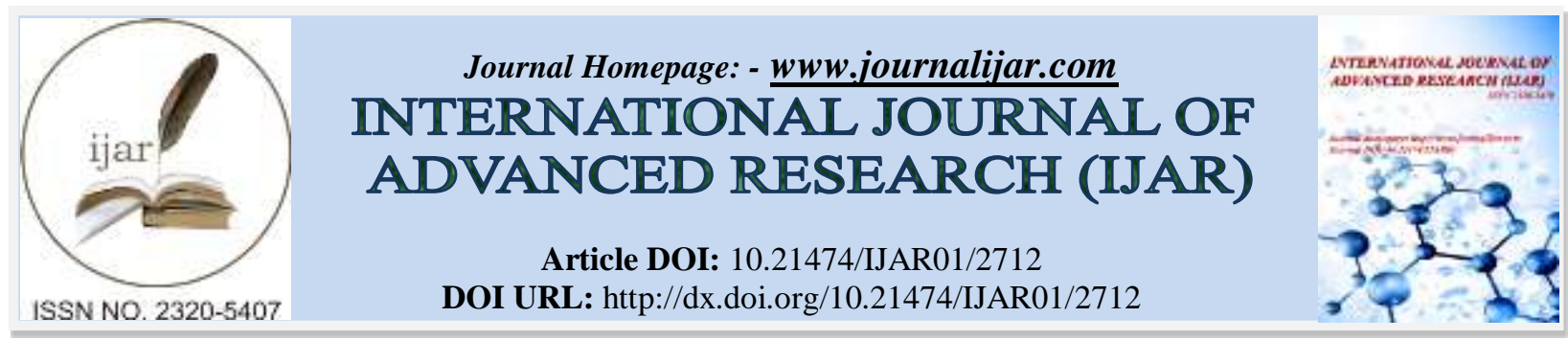

RESEARCH ARTICLE

\title{
AMELIORATING ROLE OF MELATONIN AGAINST 2.45 GHZ MICROWAVE RADIATION INDUCED OXIDATIVE STRESS IN TESTIS OF SWISS ALBINO MICE.
}

\author{
${ }^{*}$ C. L. Jonwal ${ }^{1}$, Rashmi Sisodia ${ }^{1}$, V. K. Saxena ${ }^{2}$, Archana Sharma ${ }^{1}$ and Faiza Rifat ${ }^{1}$. \\ 1. Department of Zoology, Rajasthan University, Jaipur, Rajasthan. \\ 2. Department of Physics, Rajasthan University, Jaipur, Rajasthan.
}

\section{Manuscript Info}

Manuscript History

Received: 22 October 2016

Final Accepted: 26 November 2016

Published: December 2016

Key words:-

MW radiation, Melatonin, Oxidative stress, MDA

\begin{abstract}
Purpose: Owing to growing demand of electronic appliances such as microwave oven and cell phones microwave (MW) radiations have been gradually increasing and it may adversely affect the reproductive pattern. The present study aimed to investigate the ameliorating role of melatonin against $2.45 \mathrm{GHz}$ microwave radiations induced oxidative stress in testes of Swiss albino mice. Materials and methods: 6-8 weeks old male Swiss albino mice, weighing $35 \pm 3 \mathrm{gms}$ were procured from inbred colony and were divided into four groups ( $\mathrm{n}=8 /$ group): Sham exposed, Melatonin (Mel) treated $(2 \mathrm{mg} / \mathrm{kg}$ ), Microwave exposed with $2.45 \mathrm{GHz}$ and Microwave + Melatonin $(2 \mathrm{mg} / \mathrm{kg})$ treated. Microwave exposure was given in plexiglas cages for $2 \mathrm{hrs} / \mathrm{day}$ for 30 days. The power density was measured as $0.25 \mathrm{~mW} / \mathrm{cm}^{2}$ and the specific absorption rate (SAR) was calculated to be $0.09 \mathrm{~W} / \mathrm{kg}$. Results: After completion of exposure period, mice were sacrificed and various stress related parameters: Superoxide dismutase (SOD), Glutathione peroxidase (GPx), Catalase (CAT), Malondialdehyde (MDA), Reactive oxygen species (ROS) and Protein carbonyl content were performed. Result shows that Melatonin prevented oxidative damage biochemically by significant increase $(P<0.001)$ in SOD, GPx, protein carbonyl content, testicular weight and sperm count $(P<$ $0.01)$ and decreased $(P<0.001)$ levels of MDA, CAT and ROS in MW + Mel group as compared to MW exposed group. Conclusion: Oxidative stress due to MW radiation caused adverse effects in testes of mice and melatonin supplementation proved to be a strong antioxidant and could improve the detrimental effects of microwave radiations.
\end{abstract}

Copy Right, IJAR, 2016,. All rights reserved.

\section{Introduction:-}

Humans in modern society are exposed to an ever-increasing number of electromagnetic fields (EMFs) generated from different sources of electromagnetic radiation (EMR) such as microwave ovens, civil and military radars, satellites, wireless communication, frequency modulation (FM). These electronic devices work on microwaves and are therefore constant source of microwave radiations. Microwaves (MWs) are a part of electromagnetic spectrum with frequency ranging from $300 \mathrm{MHz}$ to $300 \mathrm{GHz}$ and wavelength from $1 \mathrm{~mm}$ to $1 \mathrm{~m}$. Widespread and haphazard usage of microwaves in industrial, scientific, medical, military and domestic applications has affected male

Corresponding Author:- Rashmi Sisodia.

Address:- Department of Zoology, Rajasthan University, Jaipur, Rajasthan. 
reproductive system adversely. The leakage of EMF radiation into the environment is inescapable for human being and has posed a grave concern on human health (Crouzier et al., 2007; Wang et al., 2005). Reproductive cells or spermatozoa are of particular concern against exposure to microwave radiation as DNA integrity of spermatozoa is extremely important because they pass the genetic material to the next generation. The male reproductive system is highly vulnerable to physical factors and environmental assaults as they cause various reproductive disorders like testicular abnormalities, atypical sperm, chromosomal aberrations, infertility, testicular cancer and congenital defects in offspring (Havas, 2000; Ramadan et al., 2002; Kim et al., 2007). Chronic exposure to EMFs can enhance generation of ROS which in turn increases lipid peroxidation in addition to a decrease in antioxidant enzymes and vitamin A and E levels (Naziroglu et al., 2009; Kumar et al., 2011; Avendano et al., 2012; Atasoy et al., 2013; Aweda et al., 2003; Oksay et al., 2012). Paulraj and Behari (2004), suggested that EMFs cause non-thermal effects in tissues which in turn leads to various detrimental effects on male reproductive system. A plethora of studies have reported that male reproductive organs are highly sensitive to the extremely low frequency magnetic fields (Agarwal et al., 2003; Forgacs et al., 2006; Pasqualotto et al., 2000; Shen et al., 2000). MW radiations cause many adverse effects on reproductive system and may lead to infertility (Kesari et al., 2010, 2011; Nisbet et al., 2012). A few studies have suggested that increased oxidative stress leads to biochemically increased lipid peroxidation and free radical formation, (Kumar et al., 2011; Meral et al., 2007; Rao et al., 2008). MW radiations toxicity is mediated by oxidative stress and over production of ROS (De-Iullis et al., 2009; Oktem et al., 2005). Hence, a strong and effective anti-oxidant supplementation could be beneficial in preventing or reducing some complications of MW radiations in male reproductive system (Al- Damegh, 2012; Ilhan et al., 2004; Oral et al., 2006; Sokolovic et al., 2008). The cellular activities of spermatozoa are adversely affected by over production of free radicals due to microwave radiations (Balci et al., 2007; Kumar et al., 2010; Meral et al., 2007; Rao et al., 2008). Spermatozoa are susceptible to MW radiations because spermatozoa exhibit an inevitable lack of intrinsic oxidative enzymes like CAT, GPx, SOD as well as non-enzymatic molecules such as vitamins C or E or glutathione, which counteract the deleterious effects of oxidants in all aerobic cells. In light of the intrinsic lack of antioxidant protection with the extraordinary high lipid content of the plasma membrane, the spermatozoa are extremely vulnerable to oxidative stress (Henkel, 2011). Dasdag et al. (1999), observed abnormal changes in testicular function exposed to EMF through decreased sperm count along with narrower seminiferous tubules. Melatonin ( $N$-acetyl-5-methoxytryptamine) is a hormone produced by the pineal gland and considered to be the most powerful endogenous antioxidant. It stimulates GPx and can play a role in the prevention of oxidative damage (Reiter., 1995). Recent studies have demonstrated that Melatonin is an antioxidant, which scavenges hydroxyl radicals generated in vitro by hydrogen peroxide exposed to ultraviolet light (Bayda et al., 2001; Reiter., 1999). It is an efficient scavenger of peroxyl radicals than vitamin E ( Pieri et al., 1994; Gulcin et al., 2003). The purpose of the present study was to evaluate the effects of MW radiations induced oxidative stress in testes and potential protective role of Melatonin against oxidative stress.

\section{Materials and Methods:-}

The reagents and Melatonin were procured from Rahsiff scientific, New Delhi. The chemicals were of analytical grade (Merck and Sigma). All solutions were prepared on the day of experiment. Melatonin was administered orally to the mice ( $2 \mathrm{mg} / \mathrm{kg}$ body weight) following the work of Sokolovic et al. (2008).

\section{Experimental animals:-}

32 adult male Swiss albino mice, 6-8 weeks old, weighing 35 \pm 3 grams were used for the present study. Mice were maintained in the animal house as per the norms established by Institutional Animal Ethical Committee (IAEC). The mice were housed in clean plexiglas cages and maintained under controlled conditions of temperature with constant 12-h light and 12-h dark schedule and provided with standard mice feed and water ad libitum. The research was approved by the Departmental Ethical Committee (DEC) of Department of Zoology, University of Rajasthan for animal use.

\section{Exposure chamber:-}

The experimental study was done using microwave radiation experimental bench (figure 1). The bench consists of signal generator, isolator, attenuator, frequency meter, horn antenna and a specially designed animal cage. A graphite sheet was used to minimize the reflection of scattered beam. A rectangular box made of plexiglas was used to house the mice. The box was properly partitioned and well ventilated with holes of 1 centimeter diameter. The dimensions of the box $(4.5 \times 9 \times 9 \mathrm{~cm})$ were such that animals were comfortably placed, though they could not move much. Signal generator was capable of producing electromagnetic radiations up to $20 \mathrm{GHz}$ frequencies and maximum power 1 watt. In this experiment it was set to generate microwave radiations of frequency $2.45 \mathrm{GHz}$ and power density was measured to be $0.25 \mathrm{~mW} / \mathrm{cm}^{2}$ at the center of the box by a power meter which is a peak sensitive 
device ('RF power sensors 6900 series' and 'IFR 6960B RF power meter'; made of Aeroflex Inc., Wichita, KS, USA). The horn antenna was kept in H-plane configuration so that electric field of the waves was perpendicular to the ground surface. The electric field in the box was almost uniform because the dimensions of the box were of the order of one wavelength. Two experimental set-up were calibrated identically and were used for exposure to mice. Every day two mice were housed at a time in the box which was placed at the same location facing the horn antenna. No animal blocked the radiations falling on other animal. All the experiments were performed and repeated in a blind manner. The temperature in the chamber was maintained around $25-27^{\circ} \mathrm{C}$ throughout the experiment. The mice were exposed with $2.45 \mathrm{GHz}$ MW radiations through the horn antenna for $2 \mathrm{hrs} /$ day for 30 consecutive days. The whole-body specific absorption rate (SAR) was estimated to be $0.09 \mathrm{~W} / \mathrm{kg}$ following the method of Durney et al. (1984).

Figure 1:- Sketch of the experimental arrangement of $2.45 \mathrm{GHz}$ microwave radiations

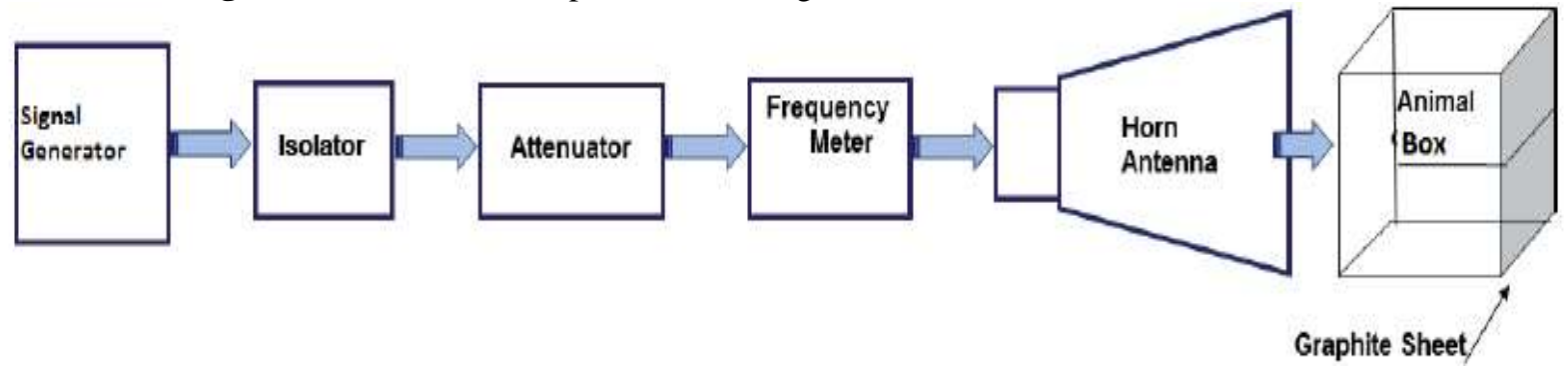

Experimental design:-

32 mice were divided into four groups, each group consists of eight animals $(\mathrm{n}=8)$.

Group I: Sham exposed (Control)

Mice were kept in a plexiglas cage and placed in-front of the horn antenna aperture for $2 \mathrm{hrs} / \mathrm{day}$ for 30 days, without energizing the system. Mice were administered distilled water as control.

\section{Group II: Melatonin treated}

Mice were kept in a plexiglas cage and placed in-front of the horn antenna aperture for $2 \mathrm{hrs} / \mathrm{day}$ for 30 days, without energizing the system. Mice were administered Melatonin solution $(2 \mathrm{mg} / \mathrm{kg}$ body weight).

\section{Group III: Microwaves exposed}

Mice were kept in a plexiglas cage and placed in-front of the horn antenna aperture and exposed to $2.45 \mathrm{GHz}$ microwaves for $2 \mathrm{hrs} / \mathrm{day}$ for 30 days. Mice were administered distilled water.

Group IV: (MW exposed + Mel)

Mice were supplemented with Melatonin $2 \mathrm{mg} / \mathrm{kg}$ once daily $1 \mathrm{hr}$ before exposure to $2.45 \mathrm{GHz}$ for $2 \mathrm{hrs} / \mathrm{day}$ for 30 consecutive days. Melatonin was administered at 08.00 AM daily to avoid its effects as neurotransmitter or neuromodulator (Drago et al., 2001). Other researchers used the same dose of melatonin in their studies (Meena et al., 2013; Koc et al., 2003; Sokolovic et al., 2008).

\section{Testicular weight:-}

The mice were sacrificed by cervical dislocation immediately after the completion of last exposure treatment. The testes were excised out, and adherent tissues were removed, and weighed by a Mettler analytical balance (BL-220H, Shimadzu Corporation, Kyoto, Japan).

\section{Sperm Count:-}

For sperm count caput and cauda were minced in $5 \mathrm{ml}$ of PBS solution and left the solution for 10 minutes to release sperms and then the solution was taken in a test tube and centrifuged for a few seconds at $100 \mathrm{rpm}$ so as to separate the sperms in the supernatant from the pellet. The supernatant for sperms count was diluted further and $10 \mu 1$ of diluted sample was placed on the hemocytometer [Neubauer improved double ruling (Fein-Optik, Blankenburg, Germany)]. Sperms were counted in 5 squares of slide and then the average was used for calculations. Total sperms in four different groups were counted by following the equation given below.

Sperm Count $=($ Dilution Factor $)($ Count in 5 squares $)\left(0.05 \times 10^{6}\right)$

\section{Protein carbonyl content:-}

For this assay, Levine et al., (1994) protocol was used for detecting and quantifying oxidative modification of proteins owing to formation of carbonyl groups in proteins due to oxidative stress. Determination of carbonyl content is based on the reaction of carbonyl groups with 2,4-dinitrophenylhydrazine to form a 2,4- 
dinitrophenylhydrazone. The assay was determined spectrophotometrically and reactive carbonyl derivatives were assessed by using DPNH molar extinction coefficient at $370 \mathrm{~nm}\left(22 \times 10^{3} \mathrm{~L} / \mathrm{mol} / \mathrm{cm}\right)$ and expressed as $\mu \mathrm{mole} / \mathrm{mg}$ protein.

\section{Lipid peroxidation (LPO):-}

For LPO assay, the amount of Malondialdehyde (MDA) was assessed by reaction of TBARS (Thiobarbituric acid reactive substances) following protocol given by Buege and Aust (1978). A 10\% tissue homogenate of testicular tissue $(100 \mathrm{mg})$ was prepared in $9 \mathrm{ml}$ of $1.15 \% \mathrm{KCl}$. Tissue homogenate $(0.8 \mathrm{ml})$ was mixed with $1.2 \mathrm{ml}$ solution of TCA $(15 \% \mathrm{w} / \mathrm{v})$, TBA $(0.375 \% \mathrm{w} / \mathrm{v})$ and $\mathrm{HCl}(0.25 \mathrm{~N})$ prepared in a $1: 1: 1$ ratio. This final mixture was heated in a water bath for $30 \mathrm{~min}$ at $90^{\circ} \mathrm{C}$ and cooled. Then $2 \mathrm{ml}$ of freshly made $\mathrm{NaOH}$ solution was added to it. After centrifugation the absorbance was recorded at $532 \mathrm{~nm}$ using a UV-vis double beam spectrophotometer. A standard curve was prepared by using TMP. After comparison with a standard curve the LPO level was expressed in nmol $\mathrm{MDA} / \mathrm{gm}$ tissue.

\section{Glutathione (GSH):-}

The GSH level was measured by the method of Moron et al., (1979). $100 \mathrm{mg}$ testicular tissue was homogenized in the sodium phosphate-EDTA buffer then $0.6 \mathrm{ml}$ DTNB solution was added to it. The optical density of the complex developed by the reaction of GSH and DTNB was measured at $412 \mathrm{~nm}$ using a UV spectrophotometer. The results were expressed as nmol GSH/100 $\mathrm{mg}$ of tissue.

\section{Superoxide Dismutase (SOD):-}

SOD was calculated following the work of Marklund and Marklund (1974). $100 \mathrm{mg}$ testicular tissue was homogenized in $1 \mathrm{ml}$ of $\mathrm{NaCl}$. Then it was centrifuged for $10 \mathrm{~min}$. then $0.1 \mathrm{ml}$ of supernatant was taken and mixed with $2.7 \mathrm{ml}$ of Tris buffer and then $0.1 \mathrm{ml}$ of pyragallol was mixed to this solution. Absorbance was taken at $420 \mathrm{~nm}$. The results were expressed as $\mu \mathrm{mole} / \mathrm{mg}$ tissue.

\section{Catalase (CAT):-}

Catalase enzyme was estimated by Aebi et al., (1984). Tissue homogenate was prepared in $5 \mathrm{ml}$ of phosphate buffer with $50 \mathrm{mg}$ of testicular tissue and centrifuged at $4^{\circ} \mathrm{C}$ for 10 minutes at $10,000 \mathrm{rpm} .0 .1 \mathrm{ml}$ of supernatant was mixed with $1 \mathrm{ml} \mathrm{PBS}$ and $0.4 \mathrm{ml} \mathrm{H}_{2} \mathrm{O}_{2}$. Absorbance was measured at $420 \mathrm{~nm}$. The results were expressed as nmole/ml.

\section{Reactive oxygen species (ROS):-}

ROS was measured by method described earlier ( Lee et al., 2006). Briefly $50 \mathrm{mg}$ of testis tissue from each mouse was taken out and it was homogenized in $1 \mathrm{ml}$ of PBS $\left(0.1 \mathrm{M} \mathrm{Na}_{2} \mathrm{HPO}_{4}, 0.1 \mathrm{M} \mathrm{KH}_{2} \mathrm{PO}_{4}, 1.37 \mathrm{M} \mathrm{NaCl}, 2.7 \mathrm{mM} \mathrm{KCl}\right.$, $\mathrm{pH}$ 7.4) using homogenizer. It was passed through $100 \mu$ pore sized cell strainer to get single cell suspension. Then 1 $\mathrm{ml}$ of RBC lysis buffer added with single cell suspension and kept for 10 minutes at RT. The suspension was centrifuged at $1200 \mathrm{rpm}$, for 10 minutes at $4^{\circ} \mathrm{C}$. The pellet was resuspended in $1 \mathrm{ml}$ of PBS and the cells were treated with 2' 7'- dichlofluorescein diacetate $(3.3 \mu \mathrm{M})$ (DCFH-DA; Molecular probes, Eugene, OR, USA). DCFHDA is permeable to cell membrane it enters the cell and hydrolysed to DCFH by cell esterases. DCFH is nonfluorescent, impermeable to the cell membrane and readily reacts with intracellular hydrogen peroxide in the presence of cell peroxides and change into fluorescent- DCF, whose florescence can be measured using flow cytometry (Rastogi et al., 2010 ; Szejda et al., 1984). The cells were incubated at RT for 10 minutes in dark and washed using PBS the cells were examined using flow cytometry (Guava technologies, CA and USA) total 5000 cells were analysed in each sample to get the mean fluorescence intensity and were corrected for auto fluorescence of the unlabeled cells.

\section{Statistical analysis:-}

The values were expressed as mean \pm SD. Data were analyzed using One-way ANOVA with Bonferroni post-hoc test. $P$ value at 0.05 was considered as the level of significance.

\section{Results:-}

Testicular weight:-

MW exposure resulted in significant reduction $(P<0.01)$ in testicular weight in exposed group $(0.15 \pm 0.012)$ as compared to the control group $(0.179 \pm 0.019$; Figure 2$)$ and Mel group $(0.185 \pm 0.017)$. Melatonin administration prior to exposure resulted in highly significant increase $(P<0.001)$ in testicular weight of MW + Mel Group $(0.175$ 
\pm 0.009 ). Reduction in testicular weight indicates that chronic microwave radiation induces atrophy in testis and Melatonin treatment ameliorates detrimental effects of MWs.

Figure 2:- Ameliorating role of Melatonin on testicular weight in Swiss albino mice exposed to $2.45 \mathrm{GHz}$ microwave radiations. The values are means $\pm(\mathrm{SD})$.

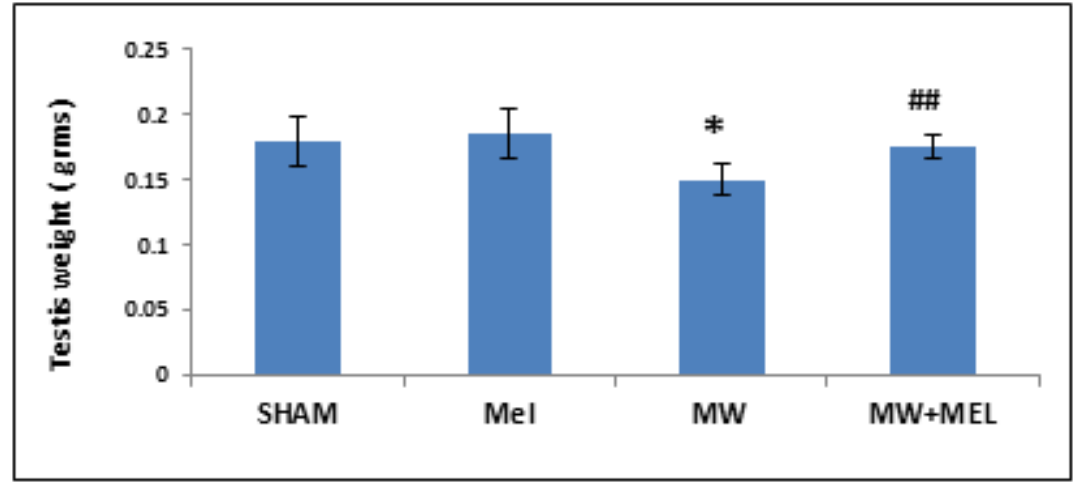

$* p<0.01$ (versus sham exposed and Mel), \#\# $p<0.001$ (versus MW)

\section{Sperm Count:-}

MW exposure resulted in highly significant reduction $(P<0.001)$ in sperm count of exposed group $(180.87 \pm 16.57)$ as compared to control group (211.12 \pm 10.72 ; Figure 3) and Mel group (213.5 \pm 11.5$)$. Melatonin administration prior to exposure resulted in significant increase $(P<0.01)$ in sperm count of MW + Mel Group $(199.87 \pm 11.67)$.

Figure 3:- The effects of Melatonin on sperm count in Swiss albino mice exposed to $2.45 \mathrm{GHz}$ microwave radiations. The values are means $\pm(\mathrm{SD})$.

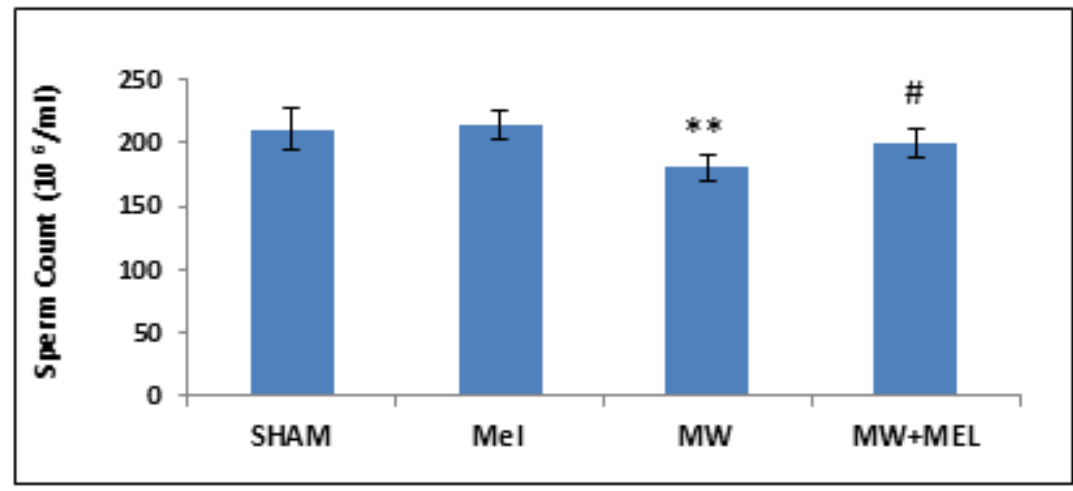

** $p<0.001$ (versus sham exposed and Mel), \# $p<0.01$ (versus MW)

\section{Protein carbonyl content:-}

MW exposure led to significant higher $(P<0.001)$ Protein carbonyl content in testicular tissue of exposed group $(6.07 \pm 0.64)$ as compared to sham exposed $(2.98 \pm 0.37$; Figure 4) and Mel group (2.34 \pm 0.56$)$. Whereas, Melatonin treatment prior to irradiation prevented the protein oxidation and could bring Protein carbonyl content levels significantly low $(P<0.001)$ in MWs + Mel group $(3.52 \pm 0.77)$. 
Figure 4:- Concentration of carbonyl groups ( $\mu \mathrm{mol} / \mathrm{mg}$ protein) in testicular tissue of Swiss albino mice exposed to $2.45 \mathrm{GHz}$ microwave radiations. The values are means $\pm(\mathrm{SD})$.

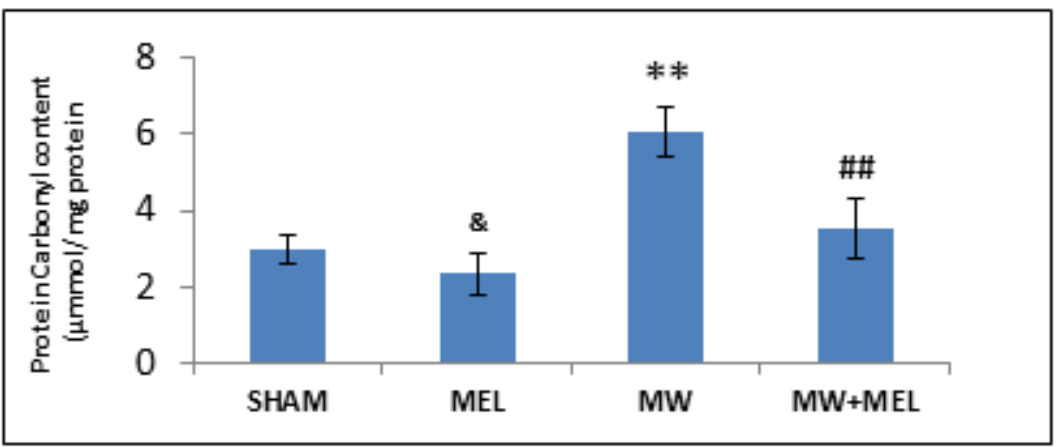

*** $p<0.001$ (versus sham exposed and Mel), \#\# $p<0.001$ (versus MW), \& $p<0.01$ (versus sham exposed)

\section{Lipid peroxidation (LPO):-}

Analysis of LPO by thiobarbituric acid reaction showed a highly significant $(P<0.001)$ increased levels of MDA in the MW exposed group $(92.78 \pm 4.09)$ as compared to sham exposed group (72.2 \pm 4.83 ; Figure 5) and Mel group $(55.6 \pm 3.9)$. Whereas Melatonin treatment prior to irradiation reversed the adverse effects of MWs and resulted in highly significant decrease $(P<0.001)$ in $\mathrm{MW}+$ Mel. Group $(78.38 \pm 5.08)$.

Figure 5:- Protective role of Melatonin on Malondialdehyde (MDA) levels in testis of Swiss albino mice exposed to $2.45 \mathrm{GHz}$ microwave radiations. The values are means $\pm(\mathrm{SD})$.

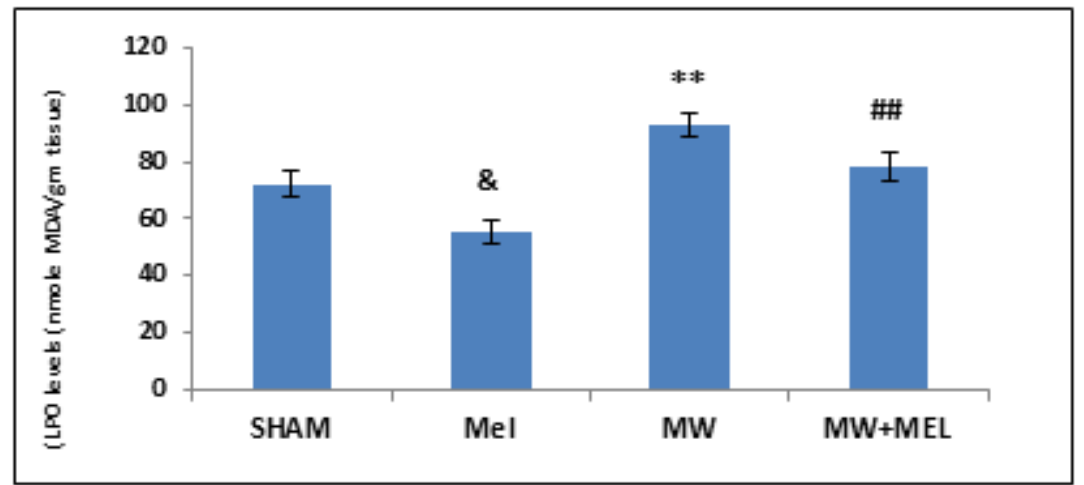

**p $p<0.001$ (versus sham exposed and Mel), \#\# $p<0.001$ (versus MW), \& $p<0.01$ (versus sham exposed)

\section{Glutathione (GSH):-}

MW exposure resulted in significant decrease $(P<0.001)$ in GSH in MW exposed group $(9.1 \pm 2.34)$ as compared to sham exposed group (15.62 \pm 4.60 ; figure 6$)$ and Mel group (16.89 \pm 1.9$)$. Meanwhile Melatonin treatment prior to irradiation resulted in highly significant increase $(P<0.001)$ in MW + Mel. Group $(14.2 \pm 2.96)$.

Figure 6:- Protective role of Melatonin on GSH levels in testis of Swiss albino mice exposed to $2.45 \mathrm{GHz}$ microwave radiations. The values are means $\pm(\mathrm{SD})$.

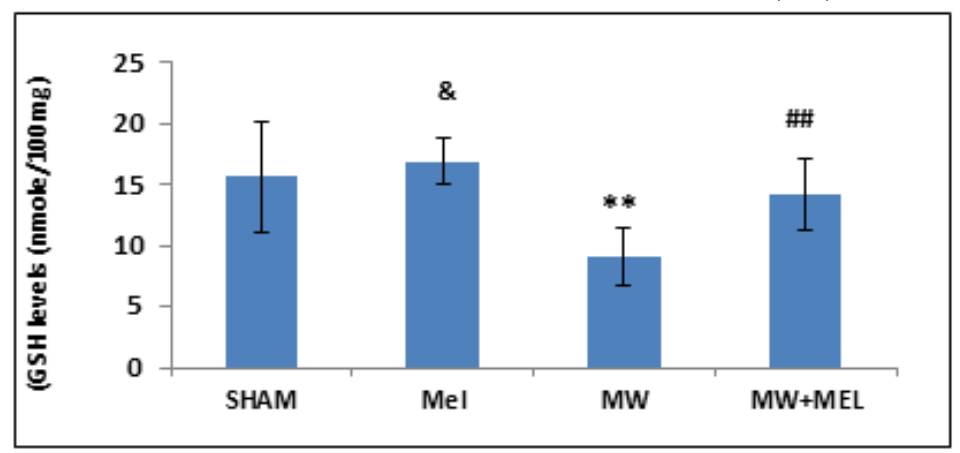


$* * p<0.001$ (versus sham exposed and Mel), \#\# $p<0.001$ (versus MW), \& $p<0.01$ (versus sham exposed)

\section{Superoxide Dismutase (SOD):-}

MW exposure resulted in highly significant $(P<0.001)$ decrease in SOD in MW exposed group $(0.67 \pm 0.198)$ as compared to sham exposed group (1.98 \pm 0.59 ; figure 7) and Mel group $(2.4 \pm 0.36)$. Meanwhile Melatonin treatment prior to irradiation resulted in highly significant increase $(P<0.001)$ in MW + Mel. Group $(1.29 \pm 0.29)$.

Figure 7:- The effects of Melatonin on SOD levels in testis of Swiss albino mice exposed to $2.45 \mathrm{GHz}$ microwave radiations. The values are means $\pm(\mathrm{SD})$.

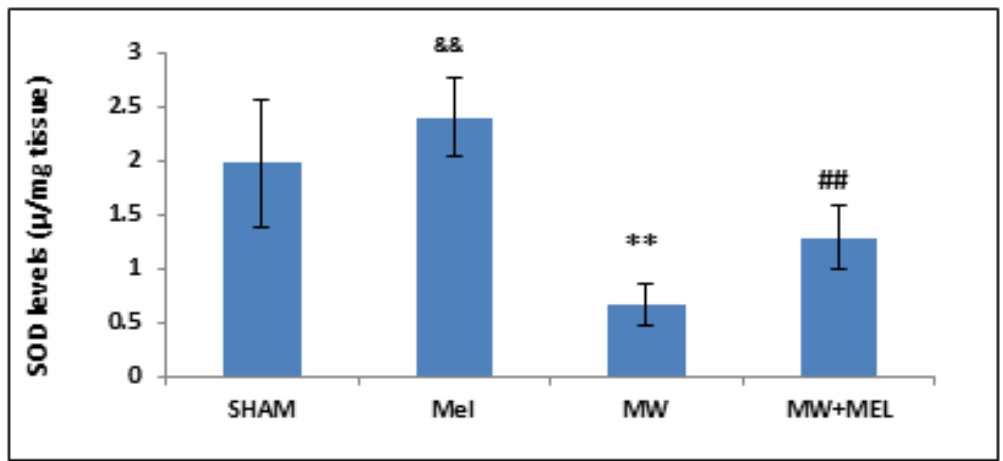

**p $<0.001$ (versus sham exposed and Mel), \#\# $p<0.001$ (versus MW), \&\& $p<0.001$ (versus sham exposed

\section{Catalase (CAT):-}

MW exposure showed a highly significant $(P<0.001)$ increase in CAT in the MW exposed group $(6.43 \pm 1.21)$ as compared to sham exposed group (3.61 \pm 0.76 ; Figure 8$)$ and Mel group $(4.37 \pm 0.48)$. Meanwhile Melatonin treatment prior to irradiation resulted in highly significant decrease $(P<0.001)$ in MW + Mel. Group $(4.51 \pm 0.51)$.

Figure 8:- The effects of Melatonin on CAT levels in testis of Swiss albino mice exposed to $2.45 \mathrm{GHz}$ microwave radiations. The values are means $\pm(\mathrm{SD})$.

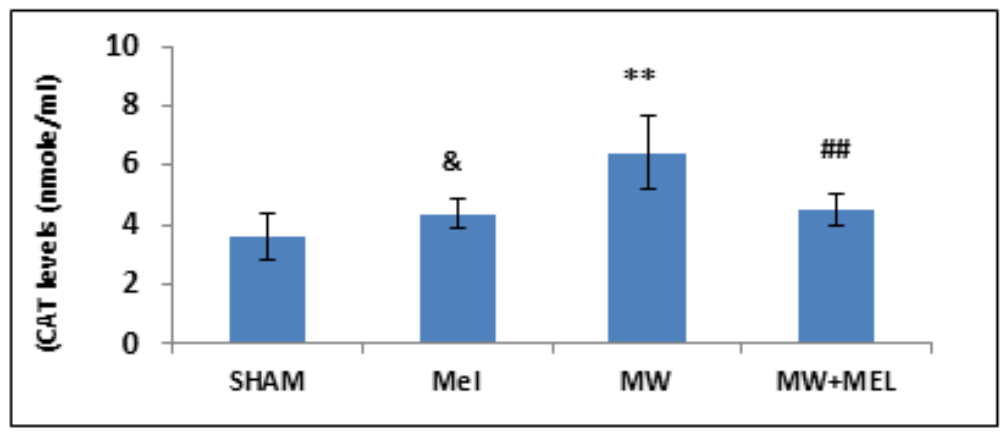

**p $p<0.001$ (versus sham exposed and Mel), \#\# $p<0.001$ (versus MW), \& $p<0.01$ (versus sham exposed)

\section{Reactive oxygen species (ROS):-}

MW exposure resulted in highly significant $(P<0.001)$ increase in ROS in MW exposed group $(27.23 \pm 3.39)$ as compared to sham exposed group (14.7 \pm 0.61 ; Figure 9$)$ and Mel group (11.82 \pm 1.8$)$. Meanwhile melatonin treatment prior to irradiation resulted in highly significant decrease $(P<0.001)$ in MW + Mel. Group $(17.16 \pm 2.60)$. 
Figure 9:- The preventive effects of Melatonin on reactive oxygen species in testis of Swiss albino mice exposed to $2.45 \mathrm{GHz}$ microwave radiation. The values are means $\pm(\mathrm{SD})$.

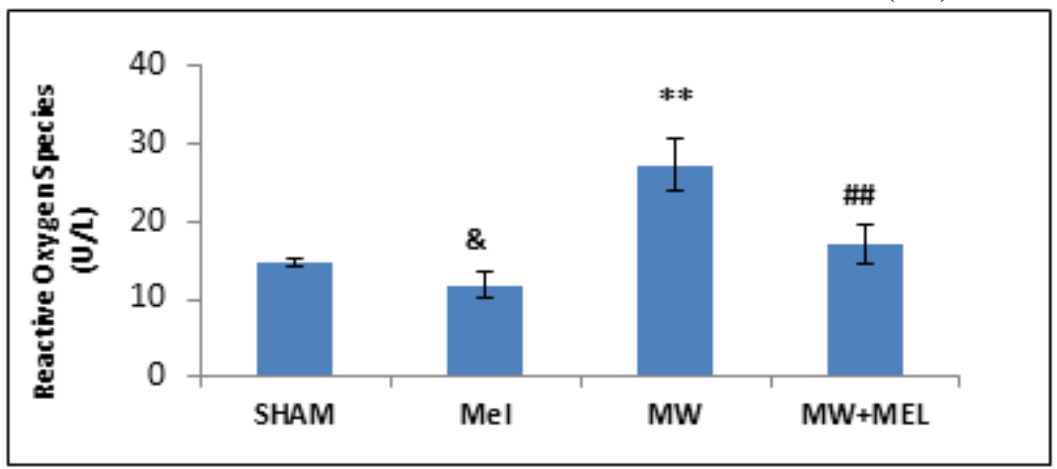

$* * p<0.001$ (versus sham exposed and Mel), \#\# $p<0.001$ (versus MW), \& $p<0.01$ (versus sham exposed)

\section{Discussion:-}

The findings of our experiments suggest that chronic MW radiation at $2.45 \mathrm{GHz}$ increased the formation of MDA and badly affected the activities of antioxidants. The generation of ROS in the testicular cells consequent upon microwave exposure may be a possible interaction between EMFs radiation and biological system. ROS and free radicals are generated in the cells by energy transfer or by electron transfer reactions induced by EMF exposure. During this process a highly reactive singlet of oxygen atom is formed which results in the sequential reduction to various molecules of the cell such as superoxide, hydrogen peroxide, and hydroxyl radical (Georgiou, C. D. 2010). The various detrimental effects of $2.45 \mathrm{GHz}$ EMFs on reproductive system were studied and EMFs were attributed to male infertility (Saygin et al., 2011; Kumar et al., 2011; Naziroglu et al., 2009; Hossmann et al., 2003). However each healthy cell is fortified with self-defense mechanism containing antioxidant enzymes: SOD, GPX and CAT so as to maintain a healthy balance of intracellular ROS. These antioxidants convert harmful substance into less harmful molecules. EMFs exposure to male reproductive system was reported to have developed testicular abnormalities, atypical sperm, chromosomal aberrations and congenital defects in offspring (Havas, 2000). The EMFs radiation emitted from various sources leads to the generation of ROS and causes male infertility (Kumar at el., 2010a,b). Free radicals cause various adverse changes in enzymes and structural proteins by introducing carbonyl groups (aldehydes and ketones) into proteins which leads to oxidative modification of proteins and may manifest in a variety of physiological and pathological processes (Levine et al., 1994). In support of above studies we have assessed the activities of antioxidant enzymes such as SOD, CAT, GPx, in mice testes and our results are in the line of earlier findings (Meena et al., 2013; Shang et al., 2004; Awad et al., 2006). Lipid peroxidation induces cellular injury to the spermatozoa due to leakage of sperm membrane fluidity (Aitken et al., 1994). The extent of microwave damage to the cell membrane of spermatozoa was monitored by measuring the amount of thiobarbituric acid reactive material (MDA) produced when polyunsaturated fatty acids in the membrane undergo peroxidation and the amount of solute leakage from cells. The increase in MDA level in our study seems to support the effect of electromagnetic field on sperms because mammalian sperm membranes contain highly unsaturated fatty acids and are also sensitive to oxygen-induced damage mediated by lipid peroxidation and free water-induced oxygen (Russo et al., 2006). In addition to this, since spermatozoa lack capacity for DNA repair on its own and therefore, would be removed from the germinal epithelium carrying the damages (Aitken and Koppers., 2011). Long-term exposure to EMF has adverse effects on the proliferation and differentiation of spermatogonia and this may be important in understanding the pathogenesis of EMFs induced male infertility proposed by Kim et al. (2007). EMF exposure causes abnormal changes in testicular function through decreased sperm count along with narrower seminiferous tubules (Dasdag et al.,1999). Lipid, Proteins, and DNA are the major categories of macromolecules that are damaged by free radicals and many studies have examined the role of Melatonin in protecting cell membrane lipids from free-radical destruction (Reiter et al., 1997; Reiter et al., 2000). Our findings show that Melatonin treatment in animals exposed to MW led to significant reduction in lipid peroxidation, protein oxidation and ROS. In vitro and in vivo studies have also shown that melatonin reduces the accumulation of the major products of lipid per oxidation when cell membranes are exposed to radical-generating agents. The mechanism for the inhibition of lipid peroxidation by Melatonin probably includes direct scavenging of the initiating radicals, especially ${ }^{*} \mathrm{OH}$ and $\mathrm{O}_{2}^{-}$. Our results demonstrated that the activities of GSH were significantly different between the sham and the MW exposed groups because it has been studied that Melatonin functions in the recycling of GSH by promoting the activities of several enzymes, including GSH-Px, glutathione reductase and glucose-6-phosphate dehydrogenase 
(Tan et al., 2000). Melatonin is also known to increase the tissue mRNA levels for SOD, the enzyme which dismutases $\mathrm{O}_{2}$ to $\mathrm{H}_{2} \mathrm{O}_{2}$, and catalase, which metabolically removes $\mathrm{H}_{2} \mathrm{O}_{2}$ from the intracellular environment, thereby further reducing the $\mathrm{H}_{2} \mathrm{O}_{2}$ levels and ${ }^{*} \mathrm{OH}$ generation (Reiter et al., 2000). Based on our findings, it may be concluded that Melatonin treatment decreases the lipid peroxidation and stimulates the antioxidant enzyme activities in radiation induced testes and thus alleviates radiation toxicity to a large extent in the testes.

\section{Conclusion:-}

It is concluded that $2.45 \mathrm{GHz} \mathrm{MW}$ radiation decreases the oxidative stress defense potential of male germ cells (spermatozoa) and it adversely affects the normal functions of testis. Reduction in GPx and SOD activity along with increased CAT, ROS, MDA and protein carbonyl content, observed in our study are clear indication of infertility pattern owing to overproduction of ROS under microwave field exposure. Melatonin has clear antioxidant properties and is likely to be a valuable drug for protection against detrimental effects of MW radiation and may be used as an antioxidant against oxidative stress. However, further experiments on this subject are needed to elucidate the mechanism of oxidative stress and protective role of Melatonin.

\section{Acknowledgement:-}

The authors are thankful to Department of Physics, University of Rajasthan, Jaipur for providing MW exposure facility.

\section{Declaration of interest:-}

The authors report no conflict of interest. The authors alone are responsible for the content and writing of the paper.

\section{References:-}

1. Aebi H. 1984. Catalase: In vitro. Eds. Colowick SP, Kaplan NO, In: Method of Enzymology, Academic press, New York. 105: 121-126.

2. Agarwal A, Saleh RA, Bedaiwy MA et al. Role of reactive oxygen species in the pathophysiology of human reproduction. Fertility and Sterility. 2003;79: 829-843.

3. Aitken RJ, Harkiss D, Buckingham D et al. Relationship between iron catalyzed lipidperoxidation potential and human sperm function. Journal of Reproductive Fertility. 1993;98: 257-265.

4. Al-Damegh M A. Rat testicular impairment induced by electromagnetic radiation from a conventional cellular telephone and the protective effects of the antioxidants vitamins C and E. Clinics. 2012; 67:785-792.

5. Atasoy HI, Gunal MY, Atasoy P, Elgun S, Bugdayci G. Immunohistopathologic demonstration of deleterious effects on growing rat testes of radiofrequency waves emitted from conventional Wi-Fi devices. J Pediatr Urol. 2013;9(2): 223-229.

6. Avendano C, Mata A, Sanchez Sarmiento CA, Doncel GF. Use of laptop computers connected to internet through Wi- Fi decreases human sperm motility and increases sperm DNA fragmentation. Fertility and Sterility. 2012;97(1): 39-45. e2.

7. Awad H, Halawa F, Mostafa T, Atta H. Melatonin hormone profile in infertile males. Int J. Androl. 2006;29:409-413.

8. Aweda MA, Gbenebitse S, Meidinyo RO. Effects of $2.45 \mathrm{GHz}$ microwave exposures on the peroxidation status in Wistar rats. Niger Postgrad Med J. 2003;10(4): 243-246.

9. Balci M, Devrim E, Durak I. Effects of mobile phones on oxidant/antioxidant balance in cornea and lens of rats. Curr. Eye Res. 2007;32:21-25.

10. Bayda G, Ercel E, Canatan H, Donder E, Akyol A. Effect of melatonin on oxidative ststus of rat brain, liver and kidney tissues under constant light exposure. Cell Biochem funct. 2001;19: 37-41.

11. Buege J A, Aust SD. 1978. Methods in Enzymology (New York: Academic) 52: 302-314.

12. Crouzier D, Testylier G, Perrin A, Debouzy JC. Which neurophysiologic effects at low level $2.45 \mathrm{GHz}$ RF exposure?. Pathol Biol (Paris). 2007;55(5): 235-241.

13. Dasdag S, Akdag MZ, Aksen F. Whole body exposure of rats to microwaves emitted from a cell phone does not affect the testes. Bioelectromagnetics. 2003; 24: 182-188.

14. De-Iullis GN, Newey RJ, King, BV, Aitken RJ. Mobile phone radiation induces reactive oxygen species production and DNA damage in human spermatozoa in vitro. PLoS One. 2009;4:e6446-e6454.

15. Drago F, Frisina M, Grech M et al. Dual effects of melatonin on barbiturate-induced narcosis in rats. Neurosci. Lett. 2001;300:176-178. 
16. Durney CH, Iskander M F, Massoudi H, Johnson CC. An empirical formula for broad band SAR calculations of prolate spheroidal models of humans and animal. In: Osepchuk JM. (Ed). Biological effects of electromagnetic radiation, New York: IEEE Press. 1984;85-90.

17. Forgacs Z, Somosy Z, Kubinyi G, Bakos J, Hudák A, Surján A, Thuróczy G. Effects of whole-body $1800 \mathrm{MHz}$ GSM-like microwave exposure on testicular steroidogenesis and histology in mice. Reproductive Toxicology. 2006; 22:111-117.

18. Georgiou CD. Oxidative stress-induced biological damage by low-level EMFs: mechanisms of free radical pair electron spin-polarization and biochemical amplification. In: Non-thermal effects and mechanisms of interaction between electromagnetic fields and living matter, Giuliani, L., Soffritti, M. (Eds), Ramazzini Institute European J. Oncology Library 2010;5: 66-113.

19. Gulcin I, Buyukokuroglu ME, Kufrevioglu OI. On the in vitro antioxidative properties of melatonin. J. Pineal. Res. 2003;34: 278-281.

20. Havas M. Biological effects of non-ionizing electromagnetic energy: A critical review of the reports by the US National Research Council and the US National Institute of Environmental Health Sciences as they relate to the broad realm of EMF bio effects. Environmental Reviews. 2000;8:173-253.

21. Hossmann KA, Hermann DM. Effects of electromagnetic radiation of mobile phones on the central nervous system. Bioelectromagnetics. 2003;24(1): 49-62.

22. Ilhan A, Gurel A, Armutcu F et al. Ginkgo biloba prevents mobile phone-induced oxidative stress in rat brain. Clin. Chim. Acta. 2004;340:153-162.

23. Kesari KK, Behari J. Effects of microwave at $2.45 \mathrm{GHz}$ radiations on reproductive system of male rats. Toxicological \& Environmental Chemistry. 2010a;92:1135-1147.

24. Kesari KK, Kumar S, Behari J. Mobile phone usage and male infertility in Wistar rats. Indian Journal of Experimental Biology. 2010b;48:987-992.

25. Kesari KK, Kumar S, Behari J. Effects of radiofrequency electromagnetic waves exposure from cellular phone on reproductive pattern in male Wistar rats. Applied Biochemistry and Biotechnology. 2011;164:546-559.

26. Kesari KK, Kumar S, Behari J. Mobile phone usage and male infertility in Wistar rats. Indian Journal of Experimental Biology. 2010; 48:987-992.

27. Kim JY, Kim HT, Moon KH, Shin HJ. Long-term exposure of rats to a $2.45 \mathrm{GHz}$ electromagnetic field: Effects on reproductive function. Korean Journal of Urology. 2007;48:1308-1314.

28. Koc M, Taysi S, Buyukokuroglu ME, Bakan N. Melatonin protects rat liver against irradiation-induced oxidative injury. J. Radiat. Res. 2003;44:211-215.

29. Kumar S, Kesari KK, Behari J. Evaluation of genotoxic effects in male wistar rats following microwave exposure. Ind. J. Exp. Biol. 2010;48:586-592.

30. Kumar S, Kesari KK, Behari J. Influence of microwave exposure on fertility of male rats. Fertility and Sterility. 2011a; 95:1500-1502.

31. Kumar S, Kesari KK, Behari J. The therapeutic effect of a pulsed electromagnetic field on the reproductive patterns of male Wistar rats exposed to a 2.45-GHz microwave field. Clinics. 2011b;66:1237-1245.

32. Kumar S, Kesari KK, Behari J. The therapeutic effect of a pulsed electromagnetic field on the reproductive patterns of male Wistar rats exposed to a 2.45-GHz microwave field. Clinics (Sao Paulo). 2011;66(7): 12371245.

33. Lee KS, Kim SR, Park SJ, Min KH, Lee KY, Jin SM, Yoo WH, Lee YC. Antioxidant down regulates interleukin-18 expression in asthma. Mol. Pharmacol. 2006;70:1184-1193.

34. Levine RL, Williams J, Stadtman E R, Shacter E. Carbonyl assays for determination of oxidatively modified proteins. Methods Enzymol. 1994;233:346-357.

35. Marklund S, Marklund G. 1974. Involvement of superoxide anion radical in auto oxidation of pyrogallol and a convenient assay for superoxide dismutase. European J Biochem 47: 469-474.

36. Meena R, Kumari K, Kumar J, Paulraj R, Verma HN, Kavindra KK. Therapeutic approaches of melatonin in microwave radiations-induced oxidative stress-mediated toxicity on male fertility pattern of Wistar rats. Electromagnetic Biology and Medicine. 2013;1536:8386.

37. Meral I, Mert H, Mert N et al. Effects of 900-MHz electromagnetic field emitted from cellular phone on brain oxidative stress and some vitamin levels of guinea pigs. Brain Res. 2007;1169:120-124.

38. Moron MS, Depierre JW, Mannervik B. 1979. Levels of GSH, GR and GST activities in rat lung and liver. BBA 582: 67-78.

39. Naziroglu M, Gumral N. Modulator effects of L-carnitine and selenium on wireless devices (2.45 GHz)-induced oxidative stress and electroencephalography records in brain of rat. Int J Radiat Biol. 2009;85(8): 680-689. 
40. Nisbet H, Ozlem Nisbet C, Akar A, Cevik M, Karayigit MO. Effects of exposure to electromagnetic field $(1.8 / 0.9 \mathrm{GHz})$ on testicular function and structure in growing rats. Research in Veterinary Science. 2012;93:1001-1005.

41. Oksay T, Naziroglu M, Dogan S, Guzel A, Gumral N, Kosar PA. Protective effects of melatonin against oxidative injury in rat testis induced by wireless $(2.45 \mathrm{GHz})$ devices. Andrologia. (In Press). 2012.

42. Oktem F, Ozguner F, Mollaoglu H et al. Oxidative damage in the kidney induced by 900 -MHz-emitted mobile phone: protection by melatonin. Arch. Med. Res. 2005;36:350-355.

43. Oral B, Guney M, Ozguner F et al. Endometrial apoptosis induced by a $900-\mathrm{MHz}$ mobile phone: preventive effects of vitamins E and C. Adv. Ther. 2006;23:957-973.

44. Pasqualotto FF, Sharma RK, Nelson DR, Thomas AJ, Agarwal, A. Relationship between oxidative stress, semen characteristics, and clinical diagnosis in men undergoing infertility investigation. Fertility and Sterility. 2000;73: 459-464.

45. Paulraj R, Behari J. Radiofrequency radiation effect on protein kinase $\mathrm{C}$ activity in rats brain. Mutation Research. 2004;585: 127-131.

46. Pieri C, Marra M, Marcheselli F, Recchioni R. Melatonin : Peroxyl radical scavenger more effective than vitamin E. Life. Sci. 1994;55: 271-276.

47. Ramadan LA, Abd-Allah AR, Aly HA, Saad-el-Din AA. Testicular toxicity effects of magnetic field exposure and prophylactic role of coenzyme Q10 and L-carnitine in mice. Pharmacological Research. 2002;46:363-370.

48. Rao, V. S, Titushkin IA, Moros EG et al. Nonthermal effects of radiofrequency-field exposure on calcium dynamics in stem cell-derived neuronal cells: Elucidation of calcium pathways. Radiat. Res. 2008;169:319-329.

49. Reiter RJ., Tan, D. X., Cabrera, J., D’Arpa, D., Sainz, R. M., Mayo, J. C., Ramos, S. The oxidant/antioxidant network: Role of melatonin. Biological Signals and Receptors. 1999;8:56-63.

50. Reiter RJ. The role of the neurohormone melatonin as a buffer against macromolecular oxidative damage. Neurochemistry International. 1995;27:453-460.

51. Reiter RJ. Melatonin aspects of exposure to low frequency electric and magnetic fields: Advances in electromagnetic fields in living systems. In J. C. Lin (Ed.), New York: Plenum. 1997;2:1-27.

52. Reiter RJ. Melatonin: Lower the high price of free radicals. News Physiol. Sci. 2000; 15: 246-250.

53. Russo A, Troncoso N, Sanchez F, Vanella A. Propolis protects human spermatozoa from DNA damage caused by benzopyrene and exogenous reactive oxygen species. Life Sciences. 2006;78:1401-1406.

54. Rastogi RP, Singh SP, Hader DP, Sinha RP. Detection of reactive oxygen species (ROS) by the oxidant sensing probe 2'7'-dichlorodihydro fluorescein diacetate in the cyanobacterium Anabaena variabilis PCC 7937. Biochem. Biophys. Res. Commun. 2010;397: 603-607.

55. Saygin M, Caliskan S, Karahan N, Koyu A, Gumral N, Uguz A. Testicular apoptosis and histopathological changes induced by a $2.45 \mathrm{GHz}$ electromagnetic field. Toxicol Ind Health. 2011;27(5): 455-463.

56. Shang X, Huang Y, Ye Z, Yu X, Gu W. Protection of melatonin against damage of sperm mitochondrial function induced by reactive oxygen species. Zhonghua Nan Ke Xue. 2004;10:604-607.

57. Shen HM, Ong CN. Detection of oxidative DNA damage in human sperm and its association with sperm function and male infertility. Free Radical Biology \& Medicine. 2000;2: 529-536.

58. Sokolovic D, Djindjic B, Nikolic J et al. Melatonin reduces oxidative stress induced by chronic exposure of microwave radiation from mobile phones in rat brain. J. Radiat. Res. 2008;49: 579-586.

59. Szejda P, Parde JW, Seeds MS, Bass D. A Flow cytometric quantitation of oxidative product formation by polymorphonuclear leukocytes during phagocytosis. J. Immunol. 1984;133: 3303-3307.

60. Tan DX, Manchester LC, Reiter RJ, Plummer BF, Limson J, Weintraup ST, Qi W. Melatonin directly scavenges hydrogen peroxide: a new metabolic path-way. Free Radical. Biol. Med. 2000; 29: 1177-1185.

61. Wang J, Sakurai T, Koyama S, Komatubara Y, Suzuki Y, Taki M et al. Effects of $2450 \mathrm{MHz}$ electromagnetic fields with a wide range of SARs on methylcholanthrene-induced transformation in C3H10T1/2 cells. J Radiat Res. 2005;46(3): 351-361. 